University of Nebraska - Lincoln

DigitalCommons@University of Nebraska - Lincoln

Publications, Agencies and Staff of the U.S.

Department of Commerce

U.S. Department of Commerce

2010

\title{
Long-term survival of humpback whales radio-tagged in Alaska from 1976 through 1978
}

Sally Mizroch

National Marine Mammal Laboratory, Alaska Fisheries Science Center, National Marine Fisheries Service

Michael F. Tillman

Scripps Institution of Oceanography, mftillman@mac.com

Susan Jurasz

SeaSearch and Sea Reach Ltd.

Janice Straley

University of Alaska Southeast, 1332 Seward Avenue, Sitka, Alaska

Olga von Ziegesar

North Gulf Oceanic Society/Eye of the Whale, P. O. Box 15191, Fritz Creek, Alaska

See next page for additional authors

Follow this and additional works at: https://digitalcommons.unl.edu/usdeptcommercepub

Part of the Environmental Sciences Commons

Mizroch, Sally; Tillman, Michael F.; Jurasz, Susan; Straley, Janice; von Ziegesar, Olga; Herman, Louis; Pack, Adam; Baker, Scott; Darling, Jim; Glockner-Ferrari, Debbie; Ferrari, Mark; Salden, Dan; and Clapham, P J., "Long-term survival of humpback whales radio-tagged in Alaska from 1976 through 1978" (2010).

Publications, Agencies and Staff of the U.S. Department of Commerce. 159.

https://digitalcommons.unl.edu/usdeptcommercepub/159

This Article is brought to you for free and open access by the U.S. Department of Commerce at DigitalCommons@University of Nebraska - Lincoln. It has been accepted for inclusion in Publications, Agencies and Staff of the U.S. Department of Commerce by an authorized administrator of DigitalCommons@University of Nebraska - Lincoln. 


\section{Authors}

Sally Mizroch, Michael F. Tillman, Susan Jurasz, Janice Straley, Olga von Ziegesar, Louis Herman, Adam Pack, Scott Baker, Jim Darling, Debbie Glockner-Ferrari, Mark Ferrari, Dan Salden, and P J. Clapham 
MARINE MAMMAL SCIENCE, **(*): ***_*** (*** 2010)

(C) 2010 by the Society for Marine Mammalogy

DOI: $10.1111 /$ j.1748-7692.2010.00391.x

This article is a U.S. government work, and is not subject to copyright in the United States.

\title{
Long-term survival of humpback whales radio-tagged in Alaska from 1976 through 1978
}

\author{
SALLY A. Mizroch
}

National Marine Mammal Laboratory, Alaska Fisheries Science Center,

National Marine Fisheries Service, 7600 Sand Point Way NE,

Seattle, Washington 98115, U.S.A.

E-mail: sally.mizroch@noaa.gov

\section{Michael F. Tillman ${ }^{1}$}

Scripps Institution of Oceanography, Center for Marine Biodiversity and Conservation,

Scripps Institution of Oceanography, 8750 Biological Grade,

La Jolla, California 92037-0202, U.S.A.

SUSAN JURASZ

SeaSearch and Sea Reach Ltd., 146 NE Yamhill Street,

Sheridan, Oregon 97378, U.S.A.

JANicE M. STRALEY

University of Alaska Southeast, 1332 Seward Avenue,

Sitka, Alaska 99835, U.S.A.

\section{Olga vON ZIEGESAR}

North Gulf Oceanic Society/Eye of the Whale, P. O. Box 15191,

Fritz Creek, Alaska 99603, U.S.A.

\section{LOUIS M. HERMAN}

ADAM A. PACK

Kewalo Basin Marine Mammal Laboratory,

The Dolphin Institute,

420 Ward Avenue, Suite 212,

Honolulu, Hawaii 96814, U.S.A.

and

University of Hawai' $i$ at Hilo (AAP),

200 W. Kawili Street,

Hilo, Hawaii 96720, U.S.A.

\footnotetext{
${ }^{1}$ Formerly at National Marine Fisheries Service. Address for correspondence: 249 Sea View Court, Encinitas, California 92024, U.S.A.
} 


\author{
SCOTT BAKER ${ }^{2}$ \\ Oregon State University, \\ Hatfield Marine Science Center, \\ 2030 SE Marine Science Drive, \\ Newport, Oregon 97365, U.S.A. \\ JIM DARLING \\ West Coast Whale Research Foundation, \\ 2155 W. 13th Avenue, \\ Vancouver, British Columbia V6K 2S2, Canada \\ Debbie Glockner-Ferrari \\ Mark Ferrari \\ Center for Whale Studies, \\ P. O. Box 1539, \\ Lahaina, Hawaii 96767, U.S.A. \\ DAN R. SALDEN \\ Hawaii Whale Research Foundation, \\ P. O. Box 1296, \\ Lahaina, Hawaii 96767, U.S.A. \\ Phillip J. Clapham \\ National Marine Mammal Laboratory, \\ Alaska Fisheries Science Center, \\ National Marine Fisheries Service, \\ 7600 Sand Point Way NE, \\ Seattle, Washington 98115 , U.S.A.
}

\begin{abstract}
Invasive tags designed to provide information on animal movements through radio or satellite monitoring have tremendous potential for the study of whales and other cetaceans. However, to date there have been no published studies on the survival of tagged animals over periods of years or decades. Researchers from the National Marine Mammal Laboratory and the Woods Hole Oceanographic Institution tracked five humpback whales with implanted radio tags in southeastern Alaska in August 1976 and July 1977, and tracked two humpback whales in Prince William Sound, Alaska, in June 1978. All seven of these individually identified humpback whales were resighted at least $20 \mathrm{yr}$ after first being tagged, and five of the seven have been observed for more than $30 \mathrm{yr}$; some of them are among the most resighted humpback whales in the North Pacific. Photos of tagging sites taken during and subsequent to tagging operations show persistent but superficial scarring and no indication of infection.

These pioneering field studies demonstrated both long-term survival of the whales and the short-term effects of deploying radio tags, which at the time were larger and more invasive than those typically used today.
\end{abstract}

\footnotetext{
${ }^{2}$ Formerly at Glacier Bay National Park and Preserve.
} 
Key words: humpback whale, Megaptera novaeangliae, approach methodology, habitat use, longevity, survival, migratory destination, photo-identification, wound healing.

Knowledge of the movements, habitat use and migratory destinations of whales and other cetaceans is extremely important to the management and conservation of populations, particularly for endangered species. Such information has come from a variety of sources, including long-distance matches through photo-identification (Baker et al. 1986, Calambokidis et al. 1996, Waite et al. 1999, Calambokidis et al. 2001, Mizroch et al. 2004, Witteveen et al. 2004), or through genotyping of individuals (Palsbøll et al. 1997, Baker et al. 1998), as well as from telemetry. The latter technique is based upon attachment to whales of tags that transmit signals to either a local receiver or to a satellite (Heide-Jørgensen et al. 2006, Zerbini et al. 2006, Mate et al. 2007). Satellite monitoring has provided a remarkable window into the detailed movements and lives of large whales, and has also been deployed with success on medium-sized odontocetes such as narwhals (Heide-Jørgensen et al. 2002, Dietz et al. 2008) and beluga whales (Hobbs et al. 2005) as well as smaller odontocetes (Hanson 2007, Andrews et al. 2008, Schorr et al. 2009). However, because attachments of tags to whales to ensure long-term retention usually involve invasive devices that penetrate the blubber, and sometimes also the muscle, concern has been expressed regarding the impact of such attachments on the health and survival of tagged animals.

Beginning in the early 1960s, researchers at the Woods Hole Oceanographic Institution (WHOI) began developing radio tags designed to attach to whales and to broadcast signals so that their movements and behaviors could be locally tracked using a VHF receiver. The early attempts were focused on North Atlantic right whales, Eubalaena glacialis (Schevill and Watkins 1966, Watkins 1978). Although the attachment methods appeared to be successful, the earliest tags did not transmit signals that could be tracked with the technology available at that time.

By December 1975 the Watkins team had developed an implantable tag based in part on Discovery-type marks (Watkins 1979, Watkins et al. 1980). The original Discovery mark was a $24 \mathrm{~cm}$ steel tube tipped with a conical lead point $38 \mathrm{~mm}$ long, and fired from a 12-gauge shotgun propelled by a pelletless shell (Rayner 1940). When properly implanted, the Discovery mark was completely buried in the blubber and/or muscle, and could be recovered only when the whale was killed and the carcass was flensed. Therefore, Discovery marks could provide only an initial (marking) location and a final (killing) location, and only if the marked whale was subsequently killed. In contrast, radio tags can in theory provide continuous data on both location and diving behaviors.

In 1976 collaboration began between WHOI and researchers at the National Marine Mammal Laboratory (NMML), Alaska Fisheries Science Center (which at the time was called the Marine Mammal Division (MMD), Northwest and Alaska Fisheries Center). The NMML conducted field operations to test and evaluate the new tags on humpback whales (Megaptera novaeangliae) in southeastern Alaska in 1976 and 1977, and WHOI evaluated the tag performance on both humpback and fin whales (Balaenoptera physalus) in Prince William Sound, Alaska in 1978 (Watkins et al. 1981). 
Because the pigmentation patterns on the ventral surface of the tail are unique to each humpback whale (Katona et al. 1979), the field teams photographed the tail flukes of the humpback whales being radio tagged to provide a way to subsequently reidentify an individual whale if its tag failed to transmit signals, or if the team was unable to track it with a direction-finding receiver. Subsequent observations of these whales might provide insight into tag failures, or show evidence of harmful effects such as wounds or scars. Although the fluke photographs were found to be less useful in the short term for evaluating tag performance, these photographs have now proven to be invaluable for reidentifying tagged whales in the long term.

Here, we use these original photos, together with subsequent resightings, to evaluate the survival of the seven whales tagged in 1976-1978, and to assess the potential long-term impact of the tagging. We also provide some data on apparent wound healing and the persistence of epidermal scarring in two of the tagged whales.

\section{MetHods}

The NMML team field tested the implantable radio tags in southeastern Alaska in 1976 and 1977, and a WHOI team field tested the tags in Prince William Sound in 1978. The development and configuration of these tags are well described in Watkins (1979), Watkins et al. (1980) and Watkins et al. (1981). The radio tag was relatively large by today's standards. It measured $1.9 \times 29 \mathrm{~cm}$, with a $45 \mathrm{~cm}$ whip antenna, and weighed about $550 \mathrm{~g}$. Depth of penetration was limited to about $29 \mathrm{~cm}$ by a stainless steel flange at the top of the tag. Penetration was usually at an angle of about $45^{\circ}$ from the surface of the whale (Watkins 1981). The tag was implanted in the blubber using a modified rifle. In case of a missed implantation, a recovery system prevented loss of the tag. An automatic radio direction finder was used to track the tag's signal when the whale surfaced.

In both 1976 and 1977 the study area was 80-120 km south of Juneau, Alaska, including the southern end of Stephens Passage and portions of Frederick Sound. The protected inland waterways of southeastern Alaska were chosen because humpback whales congregated there for feeding purposes during summer and autumn. Thus a tagged whale was expected to remain in a limited area for several months during a period of favorable weather.

Given the overcast summer weather found in southeastern Alaska, brightly colored plastic streamers were attached to the radio tags in 1977 and greatly aided visual reidentification. The tag was implanted just behind the dorsal fin as the whale sounded. The person firing the rifle attempted to implant the tag as perpendicular to the midline as possible to maximize exposure of the antenna while the whale traveled on the surface or sounded. The 1978 tagging project was described in detail in (Watkins et al. 1981).

\section{RESULTS}

In August 1976 the NMML team had only one successful attempt at tracking a whale. The first two tags shot were successfully implanted but failed to transmit, and the whale(s) were never photo-identified; as a result, we are unable to assess resightings and survival of these animals and they are not part of this report. A third tag (No. 019) implanted on the left side about $0.25 \mathrm{~m}$ behind the dorsal fin and 
Table 1. Summary of tag locations, whale IDs, and most recent sightings of humpback whales tagged in southeastern Alaska and Prince William Sound from 1976 through 1978.

\begin{tabular}{llccccc}
\hline \hline $\begin{array}{l}\text { Tagging } \\
\text { year }\end{array}$ & $\begin{array}{c}\text { Tagging } \\
\text { area }\end{array}$ & $\begin{array}{c}\text { Tag } \\
\text { no. }\end{array}$ & $\begin{array}{c}\text { NMML } \\
\text { ID }\end{array}$ & $\begin{array}{c}\text { Most } \\
\text { recent } \\
\text { sighting }\end{array}$ & $\begin{array}{c}\text { Years between } \\
\text { first and last } \\
\text { sighting }\end{array}$ & $\begin{array}{c}\text { Presumed } \\
\text { sex }\end{array}$ \\
\hline 1976 & Southeastern Alaska & 019 & 244 & 2009 & $34 \mathrm{yr}$ & Male \\
1977 & Southeastern Alaska & 020 & 6249 & 2007 & $31 \mathrm{yr}$ & Unknown \\
1977 & Southeastern Alaska & 021 & 183 & 2009 & $33 \mathrm{yr}$ & Male \\
1977 & Southeastern Alaska & 022 & 630 & 2007 & $31 \mathrm{yr}$ & Male \\
1977 & Southeastern Alaska & $023 / 024$ & 296 & 1996 & $20 \mathrm{yr}$ & Unknown \\
1978 & Prince William Sound & 028 & 6498 & 2009 & $32 \mathrm{yr}$ & Female \\
1978 & Prince William Sound & 032 & 6511 & 1998 & $21 \mathrm{yr}$ & Male \\
\hline
\end{tabular}

$1 \mathrm{~m}$ off the midline. The research team received strong transmissions and was able to track the whale intermittently for $6 \mathrm{~d}$ over a distance of at least $75 \mathrm{~km}$ in the Frederick Sound/Stephens Passage confluence, at which time the 1976 field season concluded and brought tracking prematurely to a close.

In July 1977 the NMML team successfully implanted 5 radio tags (in four different whales) (Table 1). The first whale was tagged (Tag No. 020) on the right side just below the dorsal fin on 22 July. Tags No. 021 and 022 were implanted in two different whales on 23 July. Tag No. 021 hit low on the right side of the whale, behind the dorsal fin. Tag No. 022 hit on the left side of the whale, just below and near the leading edge of the dorsal fin. Tag No. 022 never transmitted; however, the whale concerned was resighted on 28 July and the tag was observed to be fully embedded. On 24 July the whale with Tag No. 021 was reencountered and tracked. The tag was fully embedded.

One whale was inadvertently tagged twice. On 25 July, Tag No. 023 hit near the water line on the right side of the whale, in front of and below the dorsal fin. The whale was approached about $1.5 \mathrm{~h}$ after tagging: the tag was not well implanted and over half of the tag was showing. On 26 July, Tag No. 024 hit on the left side of the same individual, below and in front of the dorsal fin.

All the tags except one (Tag No. 022) transmitted signals. Tag No. 020 did not transmit after the first day. Tag 022 was an apparent tag failure as the tag never transmitted. Tag No. 021 was shed sometime between 24 July and 15 August, but it was one of two tags that penetrated only half way into the blubber. Tag No. 023 hit the whale below the waterline and did not appear to penetrate fully. Subsequent analyses revealed that the tag had fallen out within a day because the same whale was inadvertently tagged with Tag No. 024 the next day. Tag No. 024 was tracked for $5 \mathrm{~d}$ and resighted on 9 August with its tag still implanted. The whale was recognized based on the fluke pattern and the prominent bulge on the side near the point of impact.

In June 1978, in cooperation with WHOI and The Johns Hopkins University, three humpbacks were radio-tagged and tracked in Prince William Sound (Table 1; Watkins et al. 1981). One whale was tracked for only a few hours and was never photo-identified. The other tagged whales were tracked over the period 9-25 June 1978 and showed no visible sign of infection at the sites of implantation. The radio signals allowed researchers to track the whales' movements as well as to conduct detailed studies of their behavior (Watkins et al. 1981). 


\section{Resightings of Photo-Identified, Tagged Whales}

Fluke photos taken by the field teams in southeastern Alaska and Prince William Sound were archived by researchers at the NMML who had begun systematically soliciting humpback whale photo-identification photos from a number of research groups in the late 1970s. Photos from the tagging projects (as well as other early photos) were integrated into NMMLs FlukeFinder database as it developed in the mid- to late 1980s (Mizroch et al. 1990, Mizroch and Harkness 2003). Except for the most recent sightings, all the tagged whale resightings reported below were found using the FlukeFinder matching system or earlier versions of the computer-assisted matching system. All of the whales were resighted over periods ranging from 20 to $34 \mathrm{yr}$, on dates ranging from 1976 to as recently as November 2009 (Table 1, Appendix 1).

Tag No. 019-The first humpback whale ever tagged and tracked successfully (NMML ID\#244) was tagged on 14 August 1976 near Hobart Bay, in the Stephens Passage area of southeastern Alaska. This whale has been seen over the course of many years throughout southeastern Alaska, not just in the vicinity of where it was tagged, but also in Glacier Bay and in Sitka Sound. The whale was also seen during winter months near Maui. The most recent sighting was in November 2009 in southeastern Alaska. This whale has been observed as an escort and a singer in Hawaii and was confirmed as a male based on examination of a biopsy tissue sample. ${ }^{3}$

Tag No. 020_This whale, NMML ID\#6249, was tagged on 22 July 1977 near Gambier Bay near the confluence of Stephens Passage and Frederick Sound and was most recently photographed in Frederick Sound in June 2007, not far from the original tagging location.

Tag No. 021-This whale, NMML ID\#183, was tagged on 23 July 1977 near Gambier Bay and has been seen over the course of many years in the vicinity of the tagging location and also in Sitka Sound. It was also seen during winter months off Maui. The most recent sighting was off Maui in February 2009. This whale has been observed as an escort in Hawaii and is presumed to be a male.

Tag No. 022-This whale, NMML ID\#630, was tagged on 23 July 1977 near Gambier Bay and has been seen in the vicinity of the tagging location and also in winter months off Maui. The most recent sighting was in June 2007 in Frederick Sound, southeastern Alaska, not far from the original tagging location. This whale has been observed as an escort in Hawaii and was confirmed as a male based on examination of a biopsy tissue sample.

Tag No. 023/024-This whale, NMML ID\#296, was tagged $1.2 \mathrm{~km}$ south of Gambier Bay in southeastern Alaska on 25 July 1977 and closer to Gambier Bay on 26 July 1977. This whale has been seen over the course of many years in the vicinity of the tagging location and has also been seen in winter months off Maui. The most recent sighting was in August 1996 in southeastern Alaska.

Tag No. 028-This whale, NMML ID\#6498, was tagged (yellow streamer as described in Watkins et al. 1981) near Knight Island in Prince William Sound on 9 June 1978. The whale, a known female (based on her sighting history with accompanying calves), has been seen over the course of many years in Prince William Sound; she was seen with a calf during the fall of 2008 in Prince William Sound,

\footnotetext{
${ }^{3}$ Personal communication from F. Sharpe, Alaska Whale Foundation, 4739 University Way N.E. \#1239, Seattle, WA 98105, 24 January 2010.
} 
with her most recent sighting being in January 2009. As yet, she has not been photographed in a wintering area.

Tag No. 032-This whale, NMML ID\#6511, was tagged (orange streamer as described in Watkins et al. 1981) near Knight Island in Prince William Sound on 9 June 1978 and was photographed in seven subsequent years in Prince William Sound through 1998. The whale was seen near Kodiak in 1994 and in the Revillagigedo Archipelago, Mexico, in 1997. This whale was never photographed with a calf, so could be presumed to be a male.

\section{Wound Healing and Scarification}

The field teams monitored whale behavior post-tagging and documented the tag placement as the tags began to work their way out. Tag No. 019 was photographed on 18 August 1976, $2 \mathrm{~d}$ after tagging (Fig. 1A). The photographs show that about a third of the tag was exposed as it was working its way out. Photographs of that same whale ${ }^{4}$ taken on 28 June 2003 show a healed scar and a slight bump in the area where the tag had been (Fig. 1B).

Tag No. 028 was photographed on 17 June 1978, 8 d after tagging (Fig. 2A, fig. 4 in Watkins et al. 1981) and subsequently photographed on 3 December 2008 (Fig. 2B). There is a slight bulge in the vicinity of the tag location, but the area looks smooth and well-healed.

\section{DISCUSSION}

From 1976 to 1978, accounting for duplicate tagging and some probable misses, as many as 10 different humpback whales were tagged with large implantable radio tags. Seven of those whales were photo-identified at the time of tagging, and their resighting histories could thus be studied for the purpose of this article. One whale was tagged twice over the course of $2 \mathrm{~d}$. All of the photo-identified whales have been photographed again in subsequent years over periods ranging from at least $20-34 \mathrm{yr}$ (median $=31 \mathrm{yr}$ ). The fate of the whales that were not identified cannot be determined.

There is no evidence that any of the seven photo-identified tagged whales had any long-term reaction to either the chase or close approach from a $15-20 \mathrm{~m}$ vessel, nor to implantation of the tag itself. These whales did not avoid boats and most were reapproached many times by the tagging vessel in the days after they had been tagged.

The seven tagged whales were photographed by a number of different research groups in Alaskan, Hawaiian, and Mexican waters over a long time period, and are among the most photographed whales based on the number of sightings in the FlukeFinder database. Irrespective of whether some of these whales are more likely to be resighted than others because of fidelity to study areas, or greater tolerance of vessel approach, their survival over periods of between 20 and $34 \mathrm{yr}$ is undeniable.

\footnotetext{
${ }^{4}$ This whale's dorsal fin changed greatly over the nearly $30 \mathrm{yr}$ that had elapsed between the photographs shown in Figure 1. The match was confirmed after reviewing three filmed diving sequences from the 1976 tagging field season which clearly showed the dorsal fin and this individual's very distinctive tail flukes (see http://www.youtube.com/watch?v=GHc0Zt1ICkQ and Appendix 1).
} 


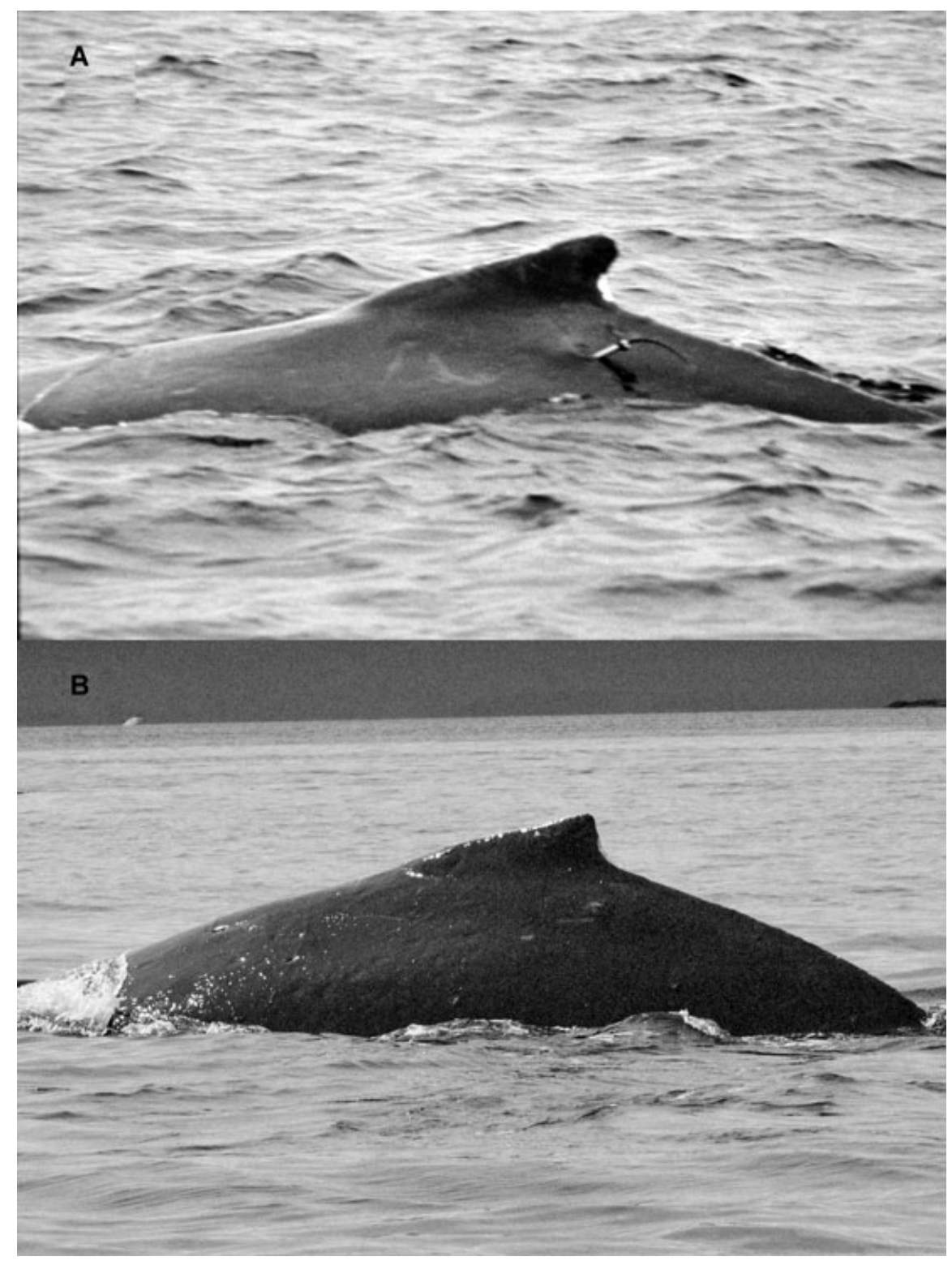

Figure 1. (A) Tag 019 on 18 August 1976 (photograph by A. A. Wolman). (B) Tag 019 on 28 June 2004 (photograph by Heather Riley).

The extensive sighting histories strongly suggest that the tagging events did not affect their health in either the short or the long term. Five of these whales have sighting histories of at least $30 \mathrm{yr}$ subsequent to tagging, and all were seen over at least a $20-y r$ period post-tagging. At least one of the whales, Tag No. 028 (NMML ID\#6498) was a female who has produced calves at regular intervals and was most 


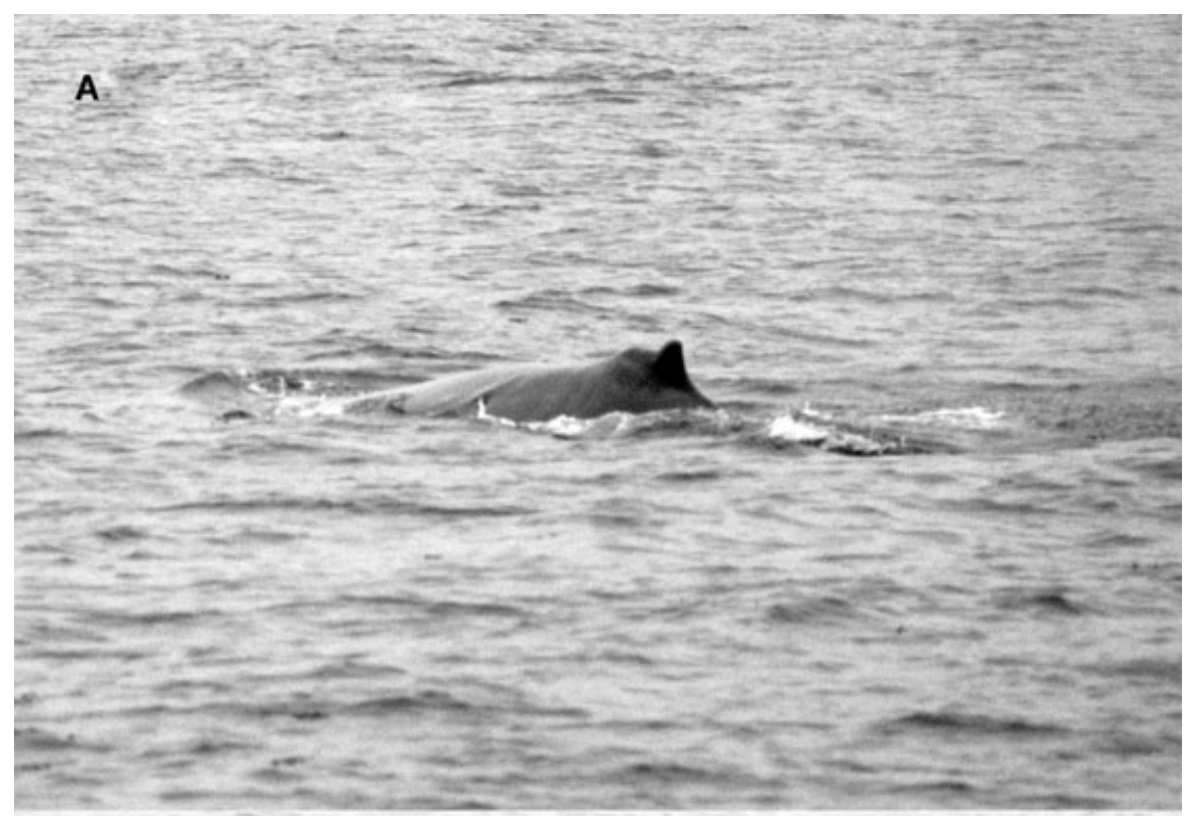

B

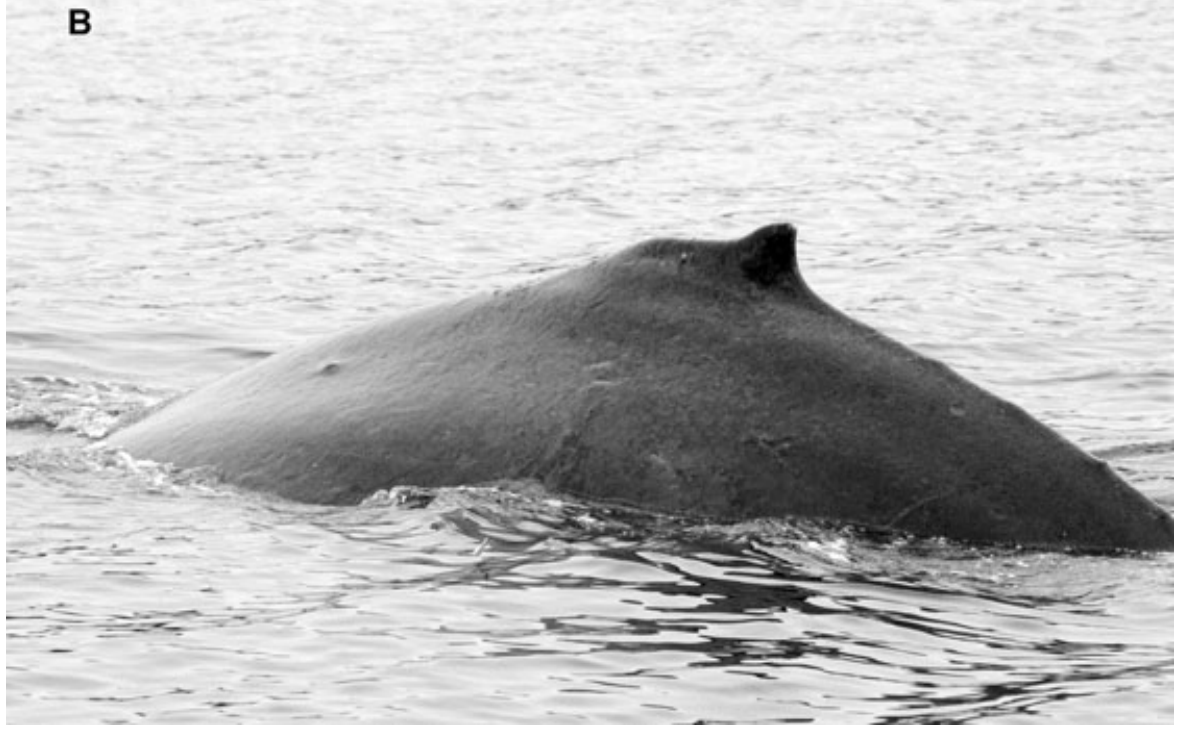

Figure 2. (A) Tag 028 on 17 June 1978 (photograph by A. A. Wolman). (B) Tag 028 on 3 December 2008 (photograph by John Moran).

recently observed with a calf in fall of 2008. One of the resighted whales, Tag No. $023 / 024$, was tagged twice in $2 \mathrm{~d}$.

The tags used in this study were large by current standards. Current technology uses tags of about $375 \mathrm{~g}$ and a total tag length from tip to stopper $\leq 26 \mathrm{~cm}$ compared to $550 \mathrm{~g}$ and $29 \mathrm{~cm}$ used on these whales. 
These field studies and the subsequent follow-up work have answered some important questions concerning the impacts upon survival from invasive research methodologies and whale reactions to studies using close approaches in the field. Watkins (1981) and Watkins and Tyack (1991) documented that whale reactions to the tagging event appeared to be transient and that tagged whales did not seem to avoid the tagging boat in subsequent encounters soon after tagging. Mate et al. (2007) documented observations of behaviors and of short-term wound healing and found no evidence of either behavioral changes or health problems. The two cases for which we have a long-term photographic record of the tagging site show persistent but apparently minor scarring, and no signs of infection.

Long-term survival following injury from whaling attacks has been demonstrated in bowhead whales (Balaena mysticetus). George and Bockstoce (2008) use accounts of the discovery of old weapon fragments to document extreme longevity in bowhead whales. A number of bowheads have been found to have old weapon fragments embedded in muscle and bone while being butchered after being caught by native hunters. These included fragments from a bomb lance (a small metal cylinder fired from a shoulder gun). George and Bockstoce (2008) suggested that at least two whales hit by bomb lances were likely to have been struck sometime around 1890 . One of those whales was killed by whalers in 1980 (approximately $90 \mathrm{yr}$ after being struck) and the other was killed in 2007 (approximately $117 \mathrm{yr}$ after being struck).

The results from the pioneering tagging projects conducted on humpback whales in 1976, 1977, and 1978 validated the wisdom of using simple photographic techniques while conducting trials of high-tech instrumentation. Being able to identify individual whales immediately after tagging allows for monitoring the impact upon the whale in the short term. Sighting tagged whales years and even decades later has provided invaluable insights into the long-term effects of these experimental technologies as well. In the specific case of the radio tag developed by Watkins and others and tested by the NMML and WHOI teams over $30 \mathrm{yr}$ ago, the extensive photographic resighting records demonstrate that the tagging operation did not affect survival of the humpback whales concerned.

\section{ACKNOWLEDGMENTS}

In 1976 and 1977 the NMML team included M. F. Tillman, D. W. Rice, A. A. Wolman, and J. H. Johnson. Other cooperating scientists included C. M. Jurasz, owner of the Ginjur and an independent consultant with many years of experience studying humpback whales in southeastern Alaska; and R. S. Payne, New York Zoological Society. In 1977 additional researchers included A. A. Berzin, Pacific Research and Fisheries Center (TINRO) in Vladivostok, V. A. Zemsky, Russian Federal Research Institute of Fishery and Oceanography (VNIRO), R. V. Miller, NMFS Marine Mammal and Endangered Species Division and V. F. Galluci, University of Washington. In 1978 the WHOI team, led by W. A. Watkins, included W. E. Schevill, Romaine Maiefski, K. Moore, D. Wartzok (The Johns Hopkins University), and J. H. Johnson and A. A. Wolman (NMML). Josh London and Janice Waite (both of NMML) provided constructive review comments. Jennifer Cedarleaf (University of Alaska Southeast (UAS), Christine Gabriele (Glacier Bay National Park and Preserve) and Jeff Jacobsen (Humboldt State University) provided data on sighting histories from southeastern Alaska, 1980-2009. Craig Matkin and Eva Saulitis (North Gulf Oceanic Society), John Moran and Suzie Teerlink (Auke Bay Laboratories (ABL)), Kate and Andy McLaughlin (McLaughlin Environmental Service, MCES) provided data on sighting histories for Prince William Sound. Data collection from Prince William Sound during the fall and winters of 2006-2009 was funded by the Exxon Valdez Trustee Council through contracts to NMFS ABL, UAS, Sitka 
Sound Science Center and MCES. All data were collected under NMFS authorized scientific marine mammal research permits. John Lindsay and Paul Hillman (NOAA Ocean Media Center) provided a digitized version of the film footage taken during the tagging studies. The film footage helped confirm the humpback whale field identification for the 1976 field season. This article is dedicated to the memory of whale biologist Allen A. Wolman (1933-2009), who participated in all of these early tagging studies and curated NMMLs humpback whale photo-identification collection in the early years.

\section{Literature Cited}

Andrews, R. D., R. L. Pitman and L. T. Ballance. 2008. Satellite tracking reveals distinct movement patterns for Type B and Type C killer whales in the southern Ross Sea, Antarctica. Polar Biology 31:1461-1468.

Baker, C. S., L. M. Herman, A. Perry, W. S. Lawton, J. M. Straley, A. A. Wolman, G. D. Kaufman, H. E. Winn, H. D. Hall, J. M. Reinke and J. Ostman. 1986. Migratory movement and population structure of humpback whales (Megaptera novaeangliae) in the central and eastern North Pacific. Marine Ecology Progress Series 31:105-119.

Baker, C., L. Florez-Gonzalez, B. Abernethy, H. Rosenbaum, R. Slade, J. Capella and J. Bannister. 1998. Mitochondrial DNA variation and maternal gene flow among humpback whales of the Southern Hemisphere. Marine Mammal Science 14:721-737.

Calambokidis, J., G. Steiger, J. Evenson, K. Flynn, K. Balcomb, D. Claridge, P. Bloedel, J. Straley, C. Baker, O. vonZiegesar, M. Dahlheim, J. Waite, J. Darling, G. Ellis and G. Green. 1996. Interchange and isolation of humpback whales off California and other North Pacific feeding grounds. Marine Mammal Science 12:215-226.

Calambokidis, J., G. H. Steiger, J. M. Straley, L. M. Herman, S. Cerchio, D. R. Salden, J. Urban, J. K. Jacobsen, O. von Ziegesar, K. C. Balcomb, C. M. Gabriele, M. E. Dahlheim, S. Uchida, G. Ellis, Y. Miyamura, P. L. de Guevara, M. Yamaguchi, F. Sato, S. A. Mizroch, L. Schlender, K. Rasmussen, J. Barlow and T. J. Quinn. 2001. Movements and population structure of humpback whales in the North Pacific. Marine Mammal Science 17:769-794.

Dietz, R., M. P. Heide-Jorgensen, P. Richard, J. Orr, K. Laidre and H. C. Schmidt. 2008. Movements of narwhals (Monodon monoceros) from Admiralty Inlet monitored by satellite telemetry. Polar Biology 31:1295-1306.

George, J. C., and J. R. Bockstoce. 2008. Two historical weapon fragments as an aid to estimating the longevity and movements of bowhead whales. Polar Biology 31:751754

Hanson, M. B. 2007. Seasonal movements and habitat use of Dall's and harbor porpoises in the inland and coastal waters of Washington state as determined by radiotelemetry. Pages 53-54 in P. Sheridan, J. W. Ferguson, and S. L. Downing, eds. Report of the National Marine Fisheries Service Workshop on Advancing Electronic Tag Technologies and Their Use in Stock Assessment, 23-25 August 2005. NOAA Technical Memorandum NMFS-F/SPO-82. U.S. Department of Commerce, Seattle, WA.

Heide-Jørgensen, M. P., R. Dietz, K. L. Laidre and P. Richard. 2002. Autumn movements, home ranges, and winter density of narwhals (Monodon monoceros) tagged in Tremblay Sound, Baffin Island. Polar Biology 25:331-341.

Heide-Jørgensen, M. P., K. L. Laidre, M. V. Jensen, L. Dueck and L. D. Postma. 2006. Dissolving stock discreteness with satellite tracking: Bowhead whales in Baffin Bay. Marine Mammal Science 22:34-45.

Hobbs, R. C., K. L. Laidre, D. J. Vos, B. A. Mahoney and M. Eagleton. 2005. Movements and area use of belugas, Delphinapterus leucas, in a subarctic Alaskan estuary. Arctic 58:331-340.

Katona, S. K., B. Baxter, O. Brazier, S. Krause, J. Perkins and H. Whitehead. 1979. Identification of humpback whales by fluke photographs. Pages 33-44 in H. E. Winn and B. L. Olla, eds. The behavior of marine animals. Plenum, New York, NY. 
Mate, B., R. Mesecar and B. Lagerquist. 2007. The evolution of satellite-monitored radio tags for large whales: One laboratory's experience. Deep Sea Research Part II: Topical Studies in Oceanography 54:224-247.

Mizroch, S. A., and S. A. D. Harkness. 2003. A test of computer-assisted matching using the North Pacific humpback whale, Megaptera novaeangliae, tail flukes photograph collection. Marine Fisheries Review 65:25-37.

Mizroch, S. A., J. A. Beard and M. Lynde. 1990. Computer assisted photo-identification of humpback whales. Report of the International Whaling Commission (Special Issue 12):63-70.

Mizroch, S. A., L. M. Herman, J. M. Straley, D. A. Glockner-Ferrari, C. Jurasz, J. Darling, S. Cerchio, C. M. Gabriele, D. R. Salden and O. Von Ziegesar. 2004. Estimating the adult survival rate of central North Pacific humpback whales (Megaptera novaeangliae). Journal of Mammalogy 85:963-972.

Palsbøll, P., J. Allen, M. Bérubé, P. Clapham, T. Feddersen, P. Hammond, R. Hudson, H. Jorgensen, S. Katona, A. Larsen, F. Larsen, J. Lien, D. Mattila, J. Sigurjonsson, R. Sears, T. Smith, R. Sponer, P. Stevick and N. Øien. 1997. Genetic tagging of humpback whales. Nature 388:767-769.

Rayner, G. W. 1940. Whale marking progress and results to December 1939. Discovery Reports XIX:245-284.

Schevill, W. E., and W. A. Watkins. 1966. Radio-tagging of whales. Pages 1-15 Ref. No. WHOI-66-17, Woods Hole Oceanographic Institution Woods Hole, MA.

Schorr, G. S., R. W. Baird, M. B. Hanson, D. L. Webster, D. J. McSweeney and R. D. Andrews. 2009. Movements of satellite-tagged Blainville's beaked whales off the island of Hawai'i. Endangered Species Research 10:203-213.

Waite, J. M., M. E. Dahlheim, R. C. Hobbs, S. A. Mizroch, O. von Ziegesar-Matkin, J. M. Straley, L. M. Herman and J. Jacobsen. 1999. Evidence of a feeding aggregation of humpback whales (Megaptera novaeangliae) around Kodiak Island, Alaska. Marine Mammal Science 15:210-220.

Watkins, W. A. 1978. A radio tag for big whales. Oceanus 21:48-54.

Watkins, W. A. 1979. Projectile point for penetrating whale blubber. Deep-Sea Research Part A. Oceanographic Research Papers 26:1301-1308.

Watkins, W. A. 1981. Reactions of three species of whales Balaenoptera physalus, Megaptera novaeangliae and Balaenoptera edeni to implanted radio tags. Deep Sea Research 28A:589599.

Watkins, W. A., and P. Tyack. 1991. Reaction of sperm whales (Pbyseter catodon) to tagging with implanted sonar transponder and radio tags. Marine Mammal Science 7:409-413.

Watkins, W. A., D. Wartzok, H. B. Martin and R. Maiefski. 1980. A radio whale tag. Pages 227-241 in F. P. Diemer, F. J. Vernberg and D. Z. Mirkes, eds. Advanced concepts in ocean measurement for marine biology. University of South Carolina Press, Columbia, SC.

Watkins, W. A., K. E. Moore, D. Wartzok and J. H. Johnson. 1981. Radio tracking of finback (Balaenoptera physalus) and humpback (Megaptera novaeangliae) whales in Prince William Sound, Alaska. Deep Sea Research 28A:577-588.

Witteveen, B. H., J. M. Straley, O. Von Ziegesar, D. Steel and C. S. Baker. 2004. Abundance and mtDNA differentiation of humpback whales (Megaptera novaeangliae) in the Shumagin Islands, Alaska. Canadian Journal of Zoology 82:1352-1359.

Zerbini, A. N., A. Andriolo, M. P. Heide-Jørgensen, J. L. Pizzorno, Y. G. Maia, G. R. VanBlaricom, D. P. DeMaster, P. C. Simoes-Lopes, S. Moreira and C. Bethlem. 2006. Satellite-monitored movements of humpback whales Megaptera novaeangliae in the southwest Atlantic Ocean. Marine Ecology-Progress Series 313:295-304. 


\section{SUPPORTING INFORMATION}

The following supporting information is available for this article online:

Appendix S1. Additional sightings and photographs of whales radio-tagged in southeastern Alaska or Prince William Sound, 1976-1978. 